\title{
Kereste Fabrikası Atığından Açık-Hücreli Karbon Köpük Üretimi ve Karakterizasyonu
}

\section{Production and Characterization of Open-Celled Carbon Foams from Sawmill Waste}

\author{
Adife Şeyda Yargıç ${ }^{1 *}$, Gamze Gündüz Meriç ${ }^{2}$, Yunus Dolaş ${ }^{3}$, Nurgül Özbay ${ }^{4}$ \\ Geliş / Received: 22/10/2021 \\ Revize / Revised: 09/11/2021 \\ Kabul / Accepted: 02/12/2021
}

\section{ÖZ}

Son yıllarda, yenilenemeyen fosil yakıt-esaslı hammaddelere alternatif olarak yenilenebilir atık biyokütleden düşük maliyetli karbon köpük hazırlanması üzerindeki çalışmalar oldukça dikkat çekmektedir. Bu kapsamda gerçekleştirilen çalışmada, $i$ ) kereste fabrikası atığı olan gürgen talaşının katranından karbon köpük üretilmesi; ii) ürünün elementel bileşiminin, yapısal, morfolojik ve kristalografik özelliklerinin kimyasal aktivasyon işlemi ile çeşitlendirilmesi amaçlanmıştır. Hammaddenin elementel karbon içeriği $(\% 45,99)$ ile kıyaslandığında \%78,8888,37 oranında daha yüksek karbon içeriğine sahip karbon köpükler hazırlanmıştır. Aktivasyon işlemi ile karbon köpüğün gözenek boyut dağılımının daha homojen olduğu ve yüzey alanının 59,821 $\mathrm{m}^{2} / \mathrm{g}$ değerinden 1004,184 $\mathrm{m}^{2} / \mathrm{g}$ 'a yükseldiği, buna rağmen kristal yapının korunduğu ve benzer x-1şını kırınım profillerine sahip köpüklerin üretildiği belirlenmiştir. Ayrıca, kimyasal aktivasyon işlemi ile yapıda oluşan çatlaklara ve kırılmalara bağlı olarak artan yüzey alanına karşılık basma dayanımı değerinin düştüğü gözlenmiştir. Özetle, uygulama alanı göz önünde bulundurularak odun-esaslı karbon köpük hazırlanmasında gerçekleştirilen kimyasal aktivasyon işleminin ürün özelliklerini önemli derecede etkileyebileceği sonucuna ulaşılmıştır.

Anahtar Kelimeler-Biyozift, Gürgen Talaşı, Karbon Köpük, Piroliz

\begin{abstract}
In recent years, studies on the preparation of low-cost carbon foam from renewable waste biomass as an alternative to non-renewable fossil fuel-based raw materials have attracted considerable attention. In this study, it is aimed $i$ ) to produce carbon foam from the tar of hornbeam sawdust, which is a sawmill waste; ii) to diversify the elemental composition, structural, morphological, and crystallographic properties of the product with the chemical activation process. Carbon foams with 78.88-88.37\% higher carbon content were prepared compared to the elemental carbon content of the raw material (45.99\%). It was determined that the pore size distribution of the carbon foam was more uniform with the activation process, and the surface area increased from $59,821 \mathrm{~m}^{2} / \mathrm{g}$ to $1004,184 \mathrm{~m}^{2} / \mathrm{g}$, after all the crystal structure was preserved and foams with similar x-ray diffraction profiles were produced. In addition, it was observed that the compressive strength value decreased in response to the increased surface area due to cracks and breaks in the structure with the chemical activation process. In summary, it was concluded that the
\end{abstract}

1*Sorumlu yazar iletişim: șeyda.guler@bilecik.edu.tr (https://orcid.org/0000-0002-8671-5896)
Kimya Mühendisliği Bölümü, Bilecik Şeyh Edebali Üniversitesi, Mühendislik Fakültesi, Bilecik, Türkiye
2İletişim: gamze.gunduz@bilecik.edu.tr (https://orcid.org/0000-0001-9487-4267)
Kimya Mühendisliği Bölümü, Bilecik Şeyh Edebali Üniversitesi, Mühendislik Fakültesi, Bilecik, Türkiye
3İletişim: yunusdolas95@gmail.com (https://orcid.org/0000-0002-7220-4454)
Kimya Mühendisliği Bölümü, Bilecik Şeyh Edebali Üniversitesi, Mühendislik Fakültesi, Bilecik, Türkiye
4İletişim: nurgul.ozbay@bilecik.edu.tr (https://orcid.org/0000-0002-0666-3417)
Kimya Mühendisliği Bölümü, Bilecik Şeyh Edebali Üniversitesi, Mühendislik Fakültesi, Bilecik, Türkiye 
chemical activation process performed in the preparation of wood-based carbon foam considering the application area can significantly affect the product properties.

\section{Keywords-Biopitch, Carbon Foam, Hornbeam Shavings, Pyrolysis}

\section{GİRIŞ}

Gözenekli karbon malzemeler, katalizör destekleri [1,2], adsorbanlar [3] ve elektrot malzemeleri [4-8] olarak kullanım için oldukça ilgi çekici malzemelerdir. Farklı uygulamalar için lazer ablasyon [9], elektrik arkı [10], kimyasal-buhar ayrıştırma [11], nanodöküm [12,13], kimyasal veya fiziksel aktivasyon [14] dahil olmak üzere çeşitli yöntemler [9-15] karbon malzemeleri hazırlamak için kullanılmaktadır. Birçok doğal malzeme genellikle bol bulunur, yenilenebilirdir, ucuzdur ve yapay öncü maddelere kıyasla çevreye zararsızdır. Karbon malzemeleri üretmek için doğal biyolojik bileşenlerin kullanılması [16-18] ile düşük değerli karbon kaynaklarından yüksek kaliteli karbon malzemelerin hazırlanması, atık karbon kaynaklarının yüksek katma değerli ürünlere dönüştürülmesi sağlanmıştır [19].

Fonksiyonel karbon malzemelerin yeni bir türü olan karbon köpük, özel üç boyutlu ağsı yapısı ile üstün özellikler sergilemektedir. Genellikle kömür, kömür katranı zifti ve petrol ziftinden hazırlanan karbon köpük, hafif, iyi ısıl kararlılık, yüksek sıcaklık/korozyon/şok/gürültü direnci, ayarlanabilir ısıl ve elektriksel iletkenlik ve mikrodalga emilimi gibi özelliklere sahip, rasgele şekilli ve açık hücre yapısı ile yüzey alanı geniş olan gözenekli bir karbon malzemedir [20,21]. Başlangıçta karbon köpükler, termoset fenolik köpüklerin 1sıl bozunmasıyla üretilmiş olup, ilk karbon köpüklerin hazırlanmasında hammadde olarak organik polimer kullanılmıştır [22]. Ancak, bu tür karbon köpüğün homojen bir ağsı yapıya sahip olmasına rağmen sınırlı mekanik mukavemet sergilediği bulunmuştur. Sonrasında gerçekleştirilen çalışmalarda ise, yüksek karbon içeriğine sahip ve iyi akışkan özelliği olan mezofaz ziftlerin karbon köpük öncüsü olarak kullanılabilecek uygun bir aday olduğu keşfedilmiştir [23]. Son yıllarda araştırmacılar, köpürme yöntemleri (kendiliğinden-kabarcıklı köpürme [24], şablon [25] ve süper kritik köpürme [26]), karbonlu öncü maddeler (mezofaz zift [24], fenol-formaldehit reçinesi [27] ve karbon köpükler için potansiyel uygulamalar [24,28-30] üzerindeki çalışmalara odaklanmıştır. Kömür katranının, uygun aktivasyon koşulları ile gözenekli malzeme üretiminde kullanılmasına ilişkin çeşitli çalışmalar bulunmaktadır [31,32]. Örneğin, He vd. [33] potasyum hidroksit (KOH) aktivasyonu ile kömür katranı ziftinden $1050 \mathrm{~m}^{2} / \mathrm{g}$ mikro gözenekli alana sahip hiyerarşik gözenekli karbonlar elde etmiştir (spesifik yüzey alanı $1330 \mathrm{~m}^{2} / \mathrm{g}$ 'a kadar ulaşmaktadır). Wang vd. [32] kömür katranı ziftinden $3400 \mathrm{~m}^{2} / \mathrm{g}$ 'a kadar spesifik yüzey alanına sahip nanogözenekli karbon üretmiştir. Biyokütle katranı yüksek karbon içeriğine, düşük kül içeriğine ve termoplastik özelliklere sahip olduğundan karbonlu malzeme üretimi için umut verici bir öncü maddedir [34-36].

Karbon köpük üretimi ile ilgili yapılan çalışmalarda genellikle fosil yakıt-esaslı öncü maddelerin kullanılması hem çevresel açıdan hem de gereken ön işlemler (kükürt giderimi, polimerleşme derecesinin ayarlanması) ve uygulanan zorlayıcı çalışma koşulları (yüksek sıcaklık/basınç) göz önünde bulundurulduğunda maliyet açısından dikkat çeken kısıtlamalara sahiptir. Yenilenebilir kaynakların değerlendirilmesi kapsamında, ileri teknoloji malzemelerden biri olan karbon köpük üretiminde atık biyokütle-esaslı öncü maddelerin kullanımı ile bahsi geçen dezavantajların sınırlandırılması mümkün olmaktadır. Yapılan çalışmanın özgün yönü, literatürde yer alan fosil yakıt-esaslı karbon köpüklerin üretimine alternatif olarak kereste fabrikası atığı olan gürgen ağacı talaşından üretilen biyo-poliollerin öncü madde olarak kullanıldığı çevre dostu üretim prosedürünün uygulanması ve ürün özelliklerinin kimyasal aktivasyon işlemi ile çeşitlendirilebilmesidir. Bu çalışmada, endüstriyel atık olan gürgen ağacı talaşından sırasıyla piroliz, zift üretimi, köpükleşme ve karbonizasyon aşamaları sonrasında ayarlanabilir özelliklere sahip karbon köpük üretimi gerçekleştirilmiştir. Karbon köpük özellikleri üzerinde kimyasal aktivasyon işleminin etkisinin incelenmesi kapsamında, köpükleşme işleminden sonra potasyum hidroksit ile aktivasyon uygulanarak gözenekliliğin arttırılması amaçlanmıştır. Son aşamada ise, yapı-özellik ilişkileri hakkında bilgi edinmek amacıyla karbon köpüklerin elementel analizi ile CHN içeriğinin tespiti, yapısal, morfolojik ve kristalografik özelliklerinin incelenmesi, gözeneklilik ve basma dayanımı değerlerinin hesaplanması için kapsamlı karakterizasyon çalı̧̧maları gerçekleştirilmiştir.

\section{MATERYAL VE METOT}

\section{A. Attk Biyokütlenin Özellikleri}

Endüstriyel atık olarak kereste fabrikasından temin edilen gürgen ağacı talaşı $(G T)$ öncelikle distile su ile yıkanmış ve laboratuvar ortamında kurumaya bırakılmıştır. Ardından, Armfield FT-7A marka öğütücü 
kullanılarak hammaddenin parçacık boyutu küçültülmüş ve parçacık boyut analizi yapılarak ortalama parçacık boyutu 0,497 mm olarak belirlenmiştir. Deneylerde kullanılmak üzere, parçacık boyutu 0,425 $>$ Dp $>0,25 \mathrm{~mm}$ aralığında olacak şekilde GT elenmiştir. Hammaddenin nem (ASTM E 871-82), kül (ASTM D 1102-84), uçucu madde (ASTM E 872-82) ve sabit karbon (ASTM E 870-82) miktarlarını kapsayan kısa analizi ile holoselüloz (TS 4431), hemiselüloz, ekstraktif madde (ASTM D 1107-96), lignin (ASTM D 1106-96) ve selüloz miktarlarını belirleyen bileşen analizleri ASTM standart test yöntemleri temel alınarak gerçekleştirilmiştir [37]. Elementel analiz cihazında (Leco CNH628 S628) $950{ }^{\circ} \mathrm{C}$ 'de gerçekleştirilen organik numune yakma işlemi ile GT'nin yapısında bulunan karbon, hidrojen ve nitrojen içerikleri incelenerek bileşen analizi yapılmış ve Denklem (1)'de verilen Dulong formülüne göre kalorifik değeri belirlenmiştir. Elementel analiz işleminden elde edilen ağırlıkça \%CHN miktarlarının toplamı 100'den çıkarılarak oksijen içeriği belirlenmiştir. Bunun yanı sıra, termogravimetrik analiz (TGA, Setaram Labsys Evo) ile GT'nin 1sıl bozunma davranışı ve taramalı elektron mikroskobu (SEM, Zeiss Supra VP 40) ile yüzey morfolojisi incelenmiş, Fourier geçirimli kızılötesi spektroskopisi (FT-IR, Perkin Elmer Spectrum 100) ile fonksiyonel grupları belirlenmiştir. SEM analizi için hammadde Quorum Q 150 R ES DC Sputter cihazında vakum altında platin kaplanmıştır. FT-IR spektrumları ise $4000-400 \mathrm{~cm}^{-1} \mathrm{bant}$ aralığında $4 \mathrm{~cm}^{-1}$ spektral çözünürlüğü ile azaltılmış toplam reflektans (ATR) tekniği kullanılarak alınmıştır.

Üst 1sıl değer $(\mathrm{kj} / \mathrm{kg})=338,2 C+1442,8[H-(O / 8)]+94,2 S$

\section{B. GT'nin Pirolizi ve Katrandan Biyozift Üretim Süreci}

Piroliz işlemi paslanmaz çelikten (\#316) üretilmiş Heinze reaktörde, 1sıtma hızı $7{ }^{\circ} \mathrm{C} / \mathrm{dk}$ olacak şekilde statik ortam koşullarında gerçekleştirilmiştir. Reaktör sıcaklığı 1sıl-çift ile ölçülerek reaktörün çevresinde bulunan rezistanslı firının sistemi 1sıtması kontrollü bir şekilde gerçekleştirilmiştir. Reaktöre yerleştirilen $G T$ (15 g) $400{ }^{\circ} \mathrm{C}^{\prime}$ lik son piroliz sıcaklığına ısıtılmış ve belirgin bir gaz çıkışı görülmeyene kadar bu sıcaklıkta $20 \mathrm{dk}$ beklenmiştir. Katran ve sulu faz karışımı $0{ }^{\circ} \mathrm{C}$ 'de bulunan sıvı toplama kaplarında yoğunlaştırıldıktan sonra diklorometan ile yıkanmış, organik fazdaki çözücü döner buharlaştırıcıda ayrılarak katran verimi hesaplanmıştır. Katı ürün verimi reaktörde kalan kısım tartılarak, gaz ürün verimi ise toplam kütle denkliğinden belirlenmiştir. Piroliz ürün dağılımı belirlenirken, kuru külsüz baz (kkb) üzerinden hesaplamalar gerçekleştirilmiş ve üç deneyin ortalaması alınmıştır. Piroliz sonrasında elde edilen katı, sıvı, gaz ürünler ile oluşan sulu faz verimleri hesaplanmıştır. Buna göre, $400{ }^{\circ} \mathrm{C}$ 'de katı ürün verimi $\% 30,32$ iken gaz ürün verimi $\% 22,37$ olarak elde edilmiştir. Piroliz sıv1 ürünü \%27,36 oranında asidik sulu faz içerirken, biyozift üretiminde kullanılacak olan katran $\left(G T_{@ 400}{ }^{\circ} \mathrm{C}\right)$ verimi ise \%19,95 olarak belirlenmiştir. Hammaddenin yapısında bulunan lignin selüloz ile kıyaslandığında daha yüksek sıcaklıklarda bozunmaktadır. Bu nedenle lignin içeriğinin yüksek olması halinde, piroliz sonucu elde edilen katı ürün veriminin de fazla olduğu bilinmektedir. Yüksek sıcaklık/basınç reaktöründe karbon köpük üretiminde öncü madde olarak kullanılacak biyozift, $250{ }^{\circ} \mathrm{C}$ 'de 50 mbar vakum basıncında 24 sa boyunca gerçekleştirilen vakumlu distilasyon işlemi ile katran yapısında bulunan ağır fazdaki aromatik yapılardan elde edilmiştir. Biyoziftin yapısı aydınlatılırken kül miktarı (ASTM D 2415) ve yumuşama noktası (Mettler Toledo FP90-83 HT) tayini yapılmış, elementel analiz (Leco CNH628 S628), helyum gaz piknometresi (Micromeritics, Accupyc II 1340), termogravimetrik analiz (TGA, Setaram Labsys Evo) ve Fourier dönüşümlü kızıl ötesi spektroskopisi (FT-IR, Perkin Elmer Spectrum 100) yöntemleri uygulanmıştır.

\section{Köpükleşme, Karbonizasyon ve Aktivasyon İşlemleri, Ürün Karakterizasyonu}

Parr 4575B model reaktörde (Parr Instrument Company, USA) $450{ }^{\circ} \mathrm{C}$ 'de gerçekleştirilen biyoziftin köpükleşme işlemi ile sentezlenmiş-yeşil köpük üretilmiştir. Sentezlenmiş-yeşil köpüğün yüzey alanının arttırılması amacıyla köpük: aktivasyon ajanı oranı 1:1 olacak şekilde potasyum hidroksit (KOH) ile kimyasal aktivasyon işlemi uygulanmıştır [38]. Potasyum hidroksit yardımıyla yüzey alanının iyileştirilmesi sırasında uygulanan ısıl işlem süresince gerçekleşen kimyasal reaksiyonlar ayrıntılı olarak açıklanmıştır [35]. Son aşamada, sentezlenmiş-yeşil köpük ve aktive köpük tüp firında azot ortamında (akış hızı $100 \mathrm{~mL} / \mathrm{dk}) 5^{\circ} \mathrm{C} / \mathrm{dk}$ 1sıtma hızı ile $1050{ }^{\circ} \mathrm{C}$ 'ye 1 sitılmış ve 2 sa boyunca karbonize edilmiştir. Karbonize edilen köpükler gürgen ağacı talaşı-esaslı biyoziftten sentezlenmiş ( $G Z C F)$ veya aktive edilmiş $(G Z A C F)$ olmasına bağlı olarak kodlanmıştır. Karbon köpük üretim sürecine ait şematik diyagram Şekil 1'de sunulmuştur.

Karbon ve aktive köpüklerin karakteristik özelliklerinin incelenmesi amacıyla elementel analiz, x-1şını kırınımı (XRD, PANalytical Empyrean, $2 \theta=0-80^{\circ}$ aralığında), taramalı elektron mikroskobu (Zeiss Supra VP 40), azot sorpsiyonu (Micromeritics ASAP 2020,@77 K) teknikleri uygulanmıştır. Buna ek olarak, 0,5 mm/dak yükleme hızına sahip Shimadzu AG-IC 100KN ile basma dayanımı ölçümü gerçekleştirilmiştir. Son olarak, 


\begin{tabular}{|c|c|c|}
\hline & $\begin{array}{l}\text { BŞEÜ Fen Bilimleri Dergisi } \\
8(2), 1044-1056,2021\end{array}$ & $\begin{array}{r}\text { BSEU Journal of Science } \\
\text { https://doi.org/10.35193/bseufbd.1013724 }\end{array}$ \\
\hline${ }_{Y H}$ & & : 2458-7575 (https://dergipark.org.tr/tr/pub/bseufbd) \\
\hline
\end{tabular}

köpüklerin yığın yoğunluğu belirlenmiş ve helyum piknometresi (Micromeritics, Accupyc II 1340) ile gerçek yoğunluk değerleri ölçülerek \% gözeneklilik hesaplanmıştır.

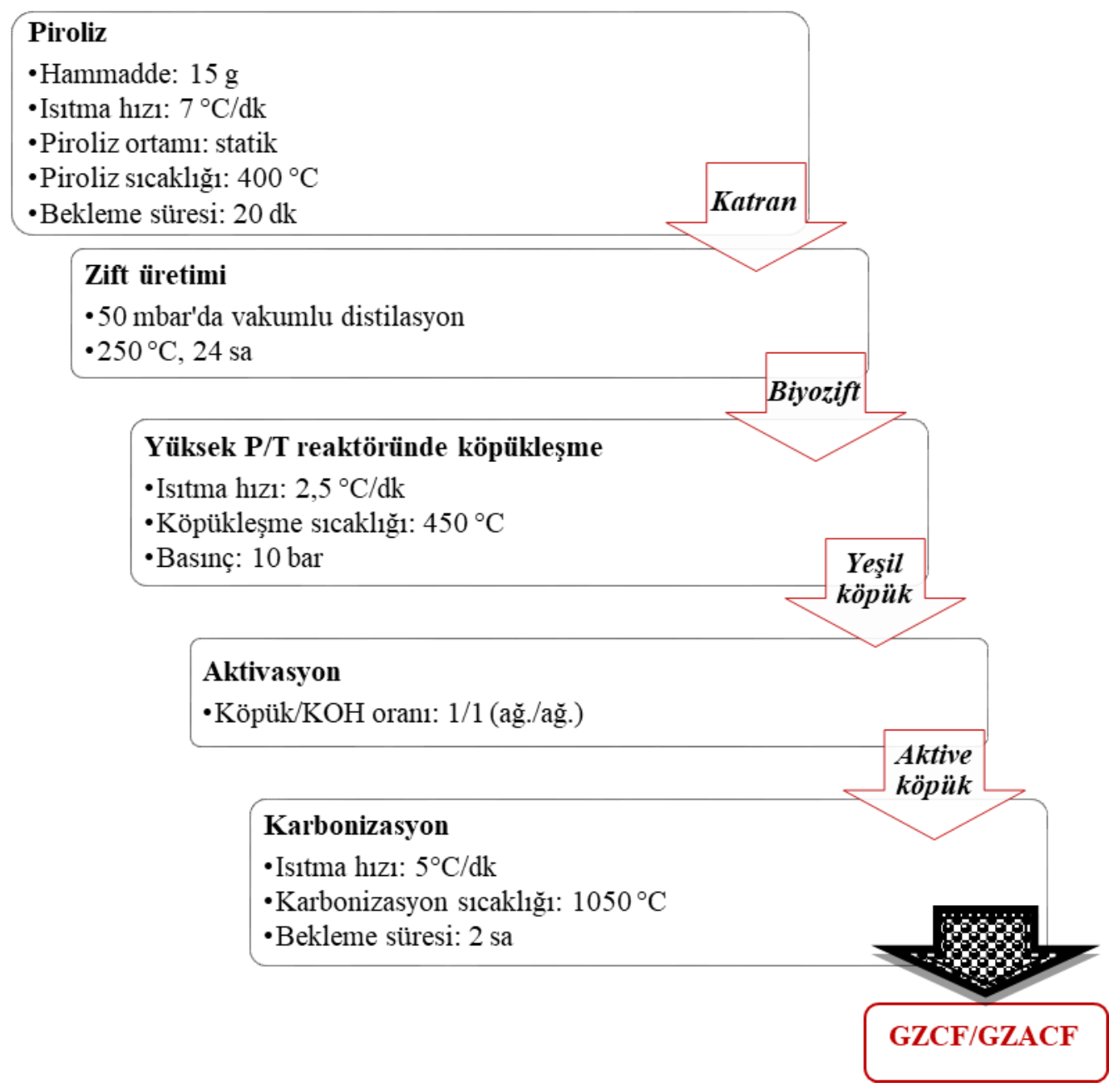

Şekil 1. Karbon köpük üretim sürecinin şematik diyagramı

\section{A. Hammadde Özellikleri}

\section{BULGULAR VE TARTIŞMA}

Piroliz işlemi uygulanacak hammadde havada kurutulmuş, ögütülmüş, altı farklı parçacık boyutu elde etmek üzere elenmiştir. Ortalama parçacık boyutundaki hammaddenin elementel, kısa ve bileşen analizleri gerçekleştirilmiştir. Gürgen ağacı talaşının temel analizi ve yaklaşık analizine ait sonuçlar Tablo 1'de sunulmuştur. Elementel analiz sonuçlarına göre, Denklem (1)'de verilen Dulong formülü kullanılarak hammaddenin kalorifik değeri 16,33MJ/kg olarak hesaplanmıştır [39]. GT'nin sahip olduğu yüksek uçucu madde (\%85,21) ve düşük kül $(\% 0,45)$ miktarları ile karbon $(\% 45,99)$ ve lignin içeriği $(\% 30,92)$ seçilen biyokütlenin karbon köpük üretiminde uygulanacak piroliz ve biyozift hazırlama işlemleri için uygun olduğunun bir göstergesidir. Biyokütlenin yapısının aydınlatılması için gerçekleştirilen kısa analiz kapsamında nem, kül, uçucu madde ve sabit karbon içerikleri incelenmekte, bununla birlikte bileşen analizi için ekstraktif madde, selüloz, hemiselüloz ve lignin miktarları tayin edilmektedir. Biyokütle yapısındaki mineral maddeleri kapsayan kül miktarının yüksek olması atık maliyetini yükseltmekte, ssıl bozunma verimini etkilemektedir. Uçucu madde miktarı katran verimi ile doğrudan ilişkili olup biyokütle ısıtıldığında ortaya çıkan yoğuşabilen/yoğuşamayan gazların varlığını göstermektedir. Piroliz işlemi sırasında katran veriminin yüksek olması için yüksek uçucu madde içeriğine sahip biyokütle tercih edilmektedir. Biyozift eldesi için ise fenolik bileşiklerce zengin olan katranın kullanılması tercih edilmekte, bu kapsamda seçilecek biyokütlenin ısıl bozunma sonrasında fenolik bileşiklerin oluşumunu sağlayacak lignini bünyesinde 
barındırması gerekmektedir. Hammaddenin fiziksel morfolojisi ve yüzey özelliklerinin incelenmesinde taramalı elektron mikroskobu tekniği kullanılmış olup, Şekil 2'de 5000x büyütme oranında alınan görüntüye göre gürgen talaşının gözenekli olmayan lifli bir morfolojiye sahip olduğu belirlenmiştir.

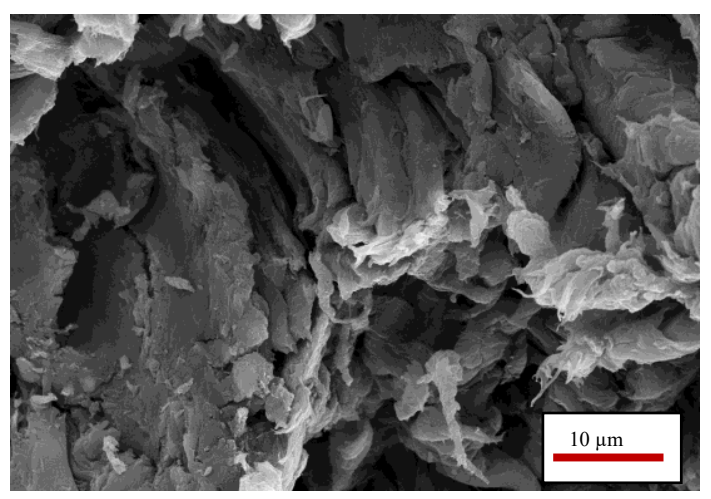

Şekil 2. Gürgen talaşının SEM görüntüsü

Tablo 1. Temel ve yaklaşık analiz sonuçları

\begin{tabular}{|c|c|c|c|}
\hline \multicolumn{4}{|c|}{ Temel Analiz } \\
\hline & $G T$ & & $G T_{@ 400{ }^{\circ} \mathrm{C}}$ \\
\hline \multicolumn{4}{|l|}{ Bileşen (\%) } \\
\hline $\mathrm{C}$ & 45,99 & & 59,94 \\
\hline $\mathrm{N}$ & 4,58 & & 4,56 \\
\hline $\mathrm{H}$ & 5,97 & & 6,97 \\
\hline $\mathrm{O}^{\mathrm{a}}$ & 43,46 & & 28,53 \\
\hline $\mathrm{H} / \mathrm{C}$ & 1,56 & & 1,40 \\
\hline $\mathrm{O} / \mathrm{C}$ & 0,71 & & 0,36 \\
\hline HHV (MJ/kg) & 16,33 & & 24,82 \\
\hline \multicolumn{4}{|c|}{ GT'nin Yaklaşık Analizi } \\
\hline Kısa Analiz & & $\% a \breve{g}$. & \\
\hline Nem & & 5,72 & \\
\hline Kül & & 0,45 & \\
\hline Uçucu Madde & & 85,21 & \\
\hline Sabit Karbon $^{\text {a }}$ & & 8,62 & \\
\hline Bileşen Analizi & & \%ăg. & \\
\hline Holoselüloz & & 67,92 & \\
\hline Hemiselüloz & & 32,58 & \\
\hline Ekstraktif Madde & & 0,72 & \\
\hline Lignin & & 30,92 & \\
\hline Selüloz ${ }^{\mathrm{a}}$ & & 35,34 & \\
\hline YığınYoğunluk $\left(\mathrm{g} / \mathrm{cm}^{3}\right)$ & & 0,26 & \\
\hline
\end{tabular}

GT’nin ısıl ve pirolitik davranışını belirlemek için uygulanan termogravimetrik analiz sonucu elde edilen TG ve dTG eğrileri Şekil 3'te gösterilmiştir. Biyokütlelerin ısıl bozunmaları kimyasal bileşimine ve yapısına bağlıdır ve genel olarak biyokütlenin ısıl bozunma eğrisi üç ana bölüme ayrılabilir. Termogravimetrik analiz sonucuna göre, ilk aşamada $100{ }^{\circ} \mathrm{C}$ civarında GT'nin yapısındaki nem uzaklaşmış, $200{ }^{\circ} \mathrm{C}^{\prime}$ den sonra piroliz reaksiyonuna bağlı olarak selüloz ve hemiselülozun parçalanması ile yüksek kütle kaybı oluşmuş, son aşamada ise $450-550^{\circ} \mathrm{C}$ aralığında ligninin yavaş bozunmasına bağlı bir kütle kaybı tespit edilmiştir [40]. Uçucu bileşiklerin oluşumundan sorumlu olan selüloz ve hemiselüloz polimerleri parçalanarak ortamdan uzaklaştıktan sonra ani kütle kayıplarının $550{ }^{\circ} \mathrm{C}$ civarında sonlandığı bulunmuştur. Hammadde yapısındaki kül ve bozunmayan karbonun miktarı ise termogravimetrik analiz sonucunda kalan kalıntıdan belirlenmektedir. 
GT yapısında bulunan fonksiyonel grupların incelenmesi amacıyla alınan FT-IR spektrumuna (Şekil 4) göre, 3600-3300 cm-1 civarında alkol/fenol veya karboksilik asitlerin varlığını gösteren geniş ve yayvan -OH bandı [41] ile $2950-2800 \mathrm{~cm}^{-1}$ aralığında alifatik yapıların ve asimetrik/simetrik C-H titreşimlerinin bulunduğuna işaret eden pikler belirlenmiştir. Esterler, ketonlar, karboksilik asitler ve aldehitlerin bulunduğunu gösteren 1770-1500 $\mathrm{cm}^{-1}$ civarındaki şiddetli pikler ise aromatik yapılardaki olefinik $\mathrm{C}=\mathrm{C}$ titreşimleri ve $\mathrm{C}=\mathrm{O}$ titreşimlerini işaret etmiştir [42]. 1480-1420 $\mathrm{cm}^{-1}$ bant aralığındaki pikler alifatik yapılardaki C-H eğilme titreşimlerini, doyurulmamış eterlerin ve fenollerin varlığının bir göstergesi olan $1430-1200 \mathrm{~cm}^{-1}$ aralığındaki pikler ise $-\mathrm{OH}$ bükülme ve C-O gerilim titreşimlerini tanımlamıştır. Son olarak, biyokütlenin yapısında bulunan lignine ait $\mathrm{C}-\mathrm{O}$ gerilim bandı 1060-1020 $\mathrm{cm}^{-1}$ civarındaki şiddetli pikler ile tespit edilmiştir [43].

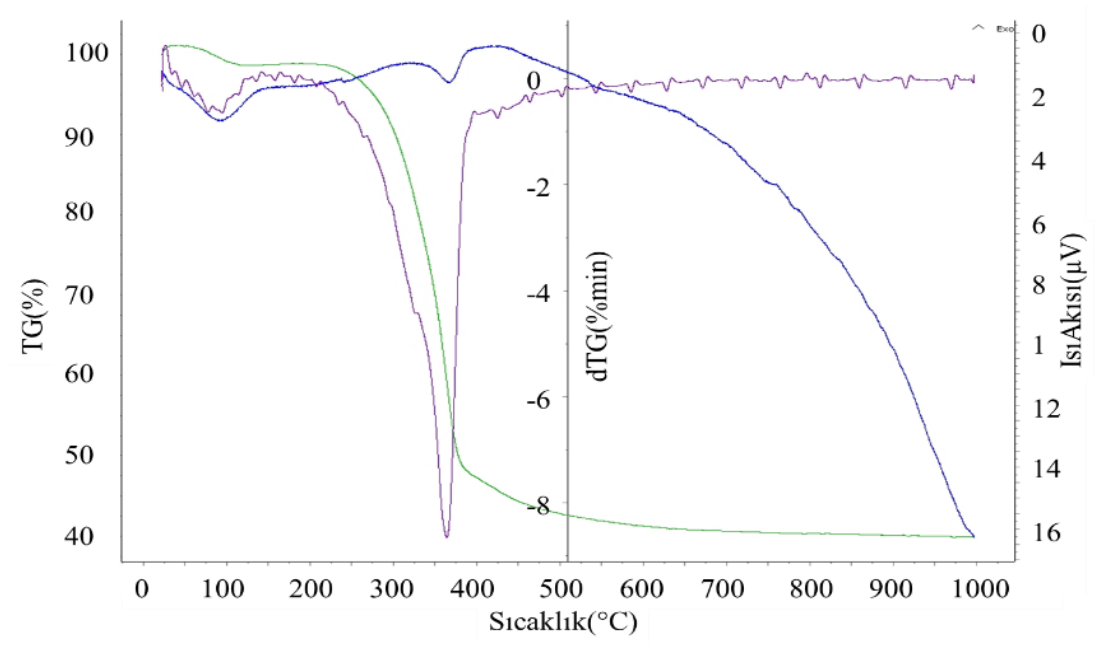

Şekil 3. GT’nin termogravimetrik analizi

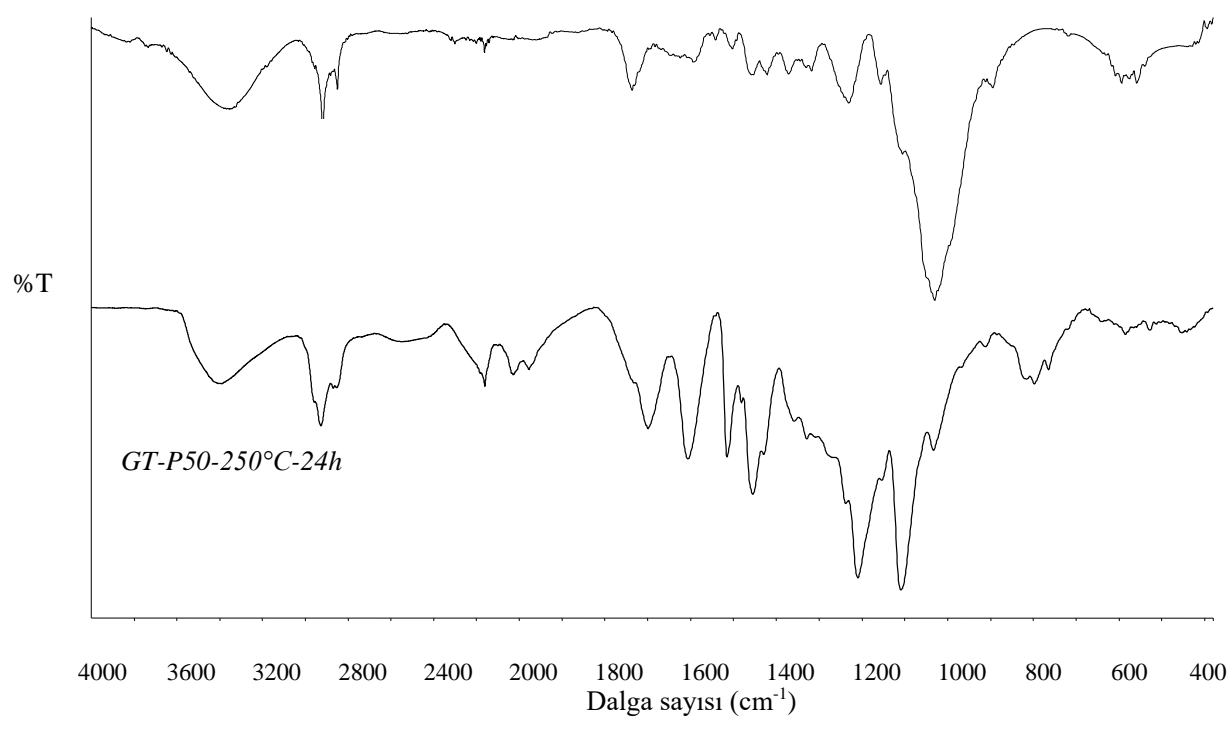

Şekil 4. Biyokütle ve biyoziftin FT-IR spektrumları

\section{B. Biyozift Özellikleri}

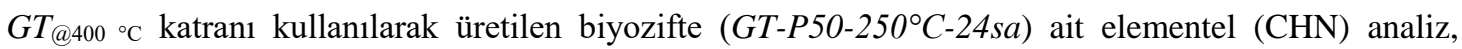
yumuşama noktası (SP) tayini, helyum piknometresi ile gerçek yoğunluk ölçümü, \%kül ve \%verim hesabı sonuçları Tablo 2'de verilmiştir. Buna göre, 50 mbar vakum basıncında $250{ }^{\circ} \mathrm{C}$ sicaklıkta 24 sa boyunca gerçekleştirilen vakumlu distilasyon işlemi sonucunda $\mathrm{C}$ içeriği \%73,927 olan biyozift \%17,02 verim ile 
üretilmiştir. Hammaddenin C içeriğgi $(\% 45,99)$ göz önünde bulundurulduğunda, biyoziftin C içeriğinin hammaddeye göre $\sim \% 61$ oranında daha fazla olduğu belirlenmiştir. Elementel analiz sonucuna göre biyoziftin $\mathrm{H} / \mathrm{C}$ ve $\mathrm{O} / \mathrm{C}$ oranı sırasıyla 1,13 ve 0,19 olarak hesaplanmıştır, bu durum üretilen katran ziftinin fosil ziftlerin aksine yüksek oksijenli ve alifatik karbonlar içerdiğini desteklemiştir [44]. Ayrıca, GT yapısında bulunan kül içeriği \%0,45 iken, biyozift yapısında \%0,104 oranında bulunan külün ihmal edilebilir düzeyde olduğu görülmüştür. Biyoziftin yumuşama noktası literatürdeki biyokütle-esaslı ziftlerin yumuşama noktaları ile uyumlu olup $125,2^{\circ} \mathrm{C}$ olarak ölçülmüştür [35,45]. Helyum piknometresi analiz sonucuna göre, biyoziftin gerçek yoğunluk değeri $1,19 \mathrm{~g} / \mathrm{cm}^{3}$ olarak ölçülmüştür. Odun katranı ziftleri için polimerizasyon derecesi ile ilgili bir terim olan asetonda çözünmeyen kısım (\%AI) \%32,3 olarak bulunmuştur [46].

Tablo 2. Biyozift özellikleri $\left(\mathrm{T}=250^{\circ} \mathrm{C}, \mathrm{P}=50 \mathrm{mbar}, \mathrm{t}=24 \mathrm{sa}\right)$

\begin{tabular}{|c|c|}
\hline Öncü Madde & $G T-P 50-250^{\circ} \mathrm{C}-24 s a$ \\
\hline $\mathrm{C}(\%)$ & 73,927 \\
\hline $\mathrm{H}(\%)$ & 6,952 \\
\hline $\mathrm{O}(\%)$ & 18,304 \\
\hline $\mathrm{N}(\%)$ & 0,817 \\
\hline Zift Verimi (\%) & 17,02 \\
\hline Kül (\%) & 0,104 \\
\hline Gerçek Yoğunluk $\left(\mathrm{g} / \mathrm{cm}^{3}\right)$ & 1,19 \\
\hline $\mathrm{AI}(\%)$ & 32,3 \\
\hline $\mathrm{SP}\left({ }^{\circ} \mathrm{C}\right)$ & 125,2 \\
\hline
\end{tabular}

Kompleks bir bileşime sahip olan ve lignin türevli bileşikleri içeren [44] biyozifte ait FT-IR spektrumu incelenerek yapısında bulunan fonksiyonel gruplar aydınlatılmıştır (Şekil 4). Termoplastik davranışa ve makromoleküler yapıya sahip olan biyoziftin yapısında alifatik ve aromatik hidrokarbonlar, fenoller, eterler, esterler ve ketonların karakteristik absorpsiyon bantları gözlenmiştir. Elementel analiz sonuçlarına göre hesaplanan $\mathrm{H} / \mathrm{C}(1,13)$ ve $\mathrm{O} / \mathrm{C}(0,19)$ oranları ile uyumlu bir şekilde $\% 18,304 \mathrm{O}$ içeriğine sahip olduğu belirlenen biyoziftin yapısındaki hidroksil ve karboksil gruplarının varlığı desteklenmiştir. FT-IR spektrumuna göre, 3600$3200 \mathrm{~cm}^{-1}$ aralığında serbest alkol ve fenolik bileşikleri için $-\mathrm{OH}$ ve $-\mathrm{COOH}, 2900 \mathrm{~cm}^{-1}$ civarında ise alkan yapısı ile ilgili olarak $\mathrm{CH}$ gerilme titreşimlerine ait pikler gözlenmiştir. $\mathrm{C} \equiv \mathrm{CH}$ alkin gerilme titreşimlerinin varlığ 2100 $\mathrm{cm}^{-1}$ bant aralığında gözlenen pik ile ispat edilmiştir. Konjuge olmayan $\mathrm{C}=\mathrm{O}$ (aldehit, keton, karboksilik asit) gerilme titreşimine ait pikler $1700 \mathrm{~cm}^{-1}$ yakınında, aromatik yapıların varlığına işaret eden $\mathrm{C}=\mathrm{C}_{\mathrm{ar}}$ gerilme bandı $1600-1400 \mathrm{~cm}^{-1}$ aralığında, gayasil ve siringil türevlerine ait $\mathrm{CH}$ bükülme bandı $1115 \mathrm{~cm}^{-1}$ ve son olarak $\mathrm{C}=\mathrm{C}$ sis bükülme bandına ait pik $750 \mathrm{~cm}^{-1}$ civarında gözlenmiştir [47-50].

Termogravimetrik analiz ile biyoziftin yüksek sıcaklık/basınç reaktöründe köpükleşme işlemi süresince uygulanan ısıtma işlemine karşı nasıl bir davranış sergileyeceği incelenmiş olup, TG ve dTG eğrileri Şekil 5'te gösterilmiştir. TG eğrisi incelendiğinde, $200{ }^{\circ} \mathrm{C}$ 'de başlayan ve $620{ }^{\circ} \mathrm{C}$ 'ye kadar sürekli olarak devam eden bozunma reaksiyonları sonucunda \%37 kalıntı oluştuğu belirlenmiştir. Elementel analiz sonucuna göre \%18,304 oranında olduğu belirlenen oksijen, köpükleşme işlemi sırasında aromatik bileşenler bakımından zengin ve kompleks biyozift yapısından ayrılarak kendiliğinden-yanmayı desteklediği için biyoziftin \%63 oranında bozulmasına neden olmuştur. 


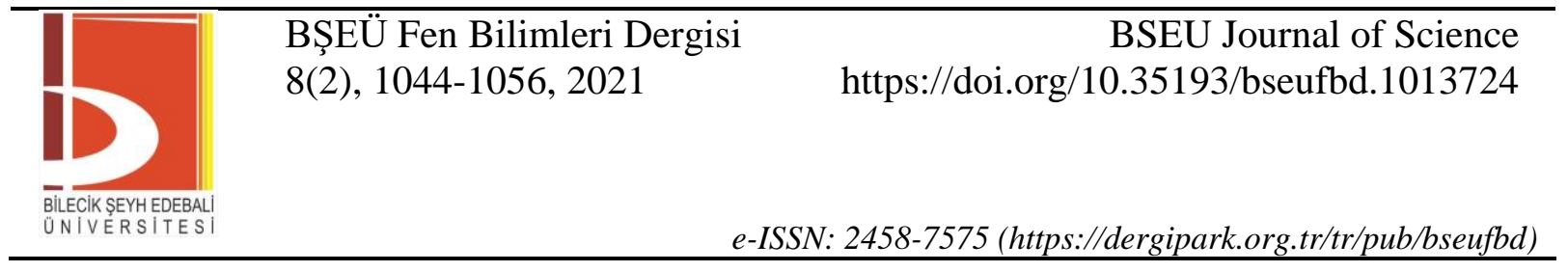

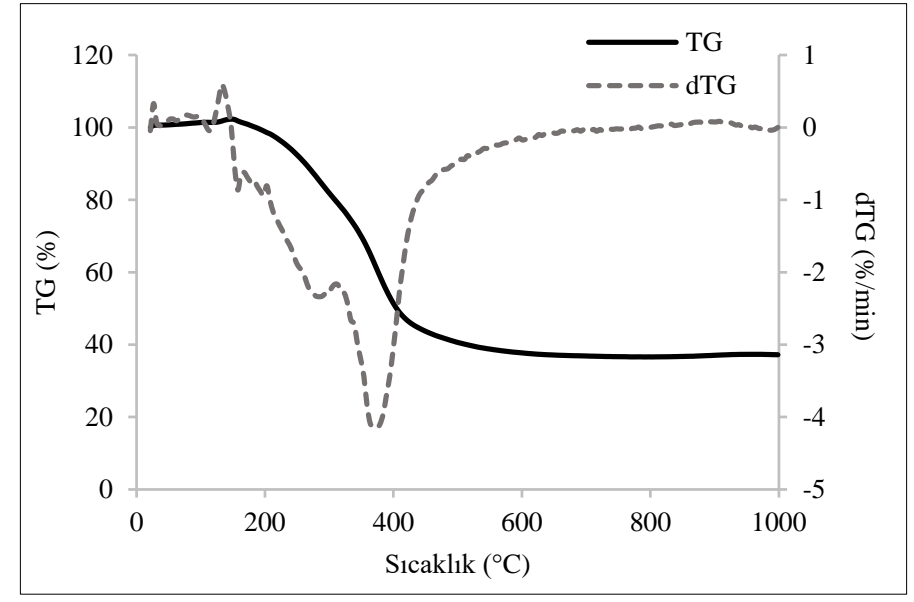

Şekil 5. GT-P50-250 ${ }^{\circ} \mathrm{C}-24 s a$ kodlu biyozifte ait TG ve dTG eğrileri

\section{Karbon Köpüklerin Karakterizasyonu}

$G T$-esaslı biyoziftten sentezlenen veya aktivasyon işleminden sonra karbonize edilen köpüklerin (GZCF ve GZACF) elementel analiz sonuçları Tablo 3'te gösterilmiştir. GT-P50-250 ${ }^{\circ} \mathrm{C}-24$ sa biyoziftinin $\% 73,327 \mathrm{C}$ ve $\% 18,304 \mathrm{O}$ içeriğine sahip olduğu göz önünde bulundurulduğunda, karbonizasyon işleminden sonra biyozift-esaslı karbon köpüklerin C içeriğinin GZCF ve GZACF için sırasıly \%86,630 ve \%82,267 olacak şekilde arttığı, O içeriğinin ise ters orantılı bir şekilde $\% 10,812$ ve $\% 15,464$ olacak şekilde azaldığ belirlenmiştir. Buna göre, köpükleşme basamağından sonra aktivasyon işlemi uygulandığında doğrudan sentezlenmiş olan karbon köpüğe oranla $\mathrm{O}$ içeriği daha yüksek ve $\mathrm{C}$ içeriği daha düşük köpük üretilmiştir.

Tablo 3. Karbon köpüklerin elementel analiz sonuçları

\begin{tabular}{llllllll}
\hline Köpük Kodu & $\mathbf{C}(\boldsymbol{\%})$ & $\mathbf{H}(\boldsymbol{\%})$ & $\mathbf{O}(\boldsymbol{\%})$ & $\mathbf{N}(\boldsymbol{\%})$ & $\mathbf{H H V}(\mathbf{M J} / \mathbf{k g})$ & $\mathbf{H} / \mathbf{C}$ & $\mathbf{O} / \mathbf{C}$ \\
\hline$G Z C F$ & 86,630 & 0,591 & 10,812 & 1,967 & 28,201 & 0,08 & 0,09 \\
$G Z A C F$ & 82,267 & 0,818 & 15,464 & 1,451 & 26,214 & 0,12 & 0,14 \\
\hline
\end{tabular}

X-1şını kırınım desenlerine göre GZCF ve GZACF karbon köpükleri için belirlenen XRD parametreleri Tablo 4'te sunulmuştur. Gürgen biyozifti-esaslı karbon köpüklerin x-ışını kırınım desenlerinde (Şekil 6), karbon esaslı malzemelere özgü $2 \theta=10^{\circ}-30^{\circ}$ aralığında gözlenen ve maksimum değeri $2 \theta^{\circ}=23^{\circ}$ civarında olan geniş bant yığıılmış grafitik bazal düzlemin $\left(\begin{array}{llll}0 & 0 & 2\end{array}\right)$ varlığı tespit edilmiştir [37,41,51-54]. Ayrıca, grafit-benzeri malzemelerdeki karbon tabakalarının iki-boyutlu diziliminin karakteristik yansımasının ise $2 \theta=41-45^{\circ}$ aralığında $\left(\begin{array}{lll}1 & 0 & 0\end{array}\right)$ ve $\left(\begin{array}{lll}1 & 0 & 1\end{array}\right)$ yansıması olarak gözlendiği bilinmektedir [55,56]. Bu kapsamda, XRD profillerinde yer alan $2 \theta=23^{\circ}$ ve $43^{\circ}$ civarındaki kırınım pikleri sırasıyla hegzagonal karbonun $\left(\begin{array}{lll}0 & 0 & 2\end{array}\right)$ ve hegzagonal grafitin $\left(\begin{array}{lll}1 & 0 & 0\end{array}\right)$ düzlemlerine [57-61]; $2 \theta=72^{\circ}$ civarındaki pik ise ortorombik grafitin [62] varlığına işaret etmektedir.

Tablo 4. GZCF ve GZACF karbon köpükleri için XRD parametreleri

\begin{tabular}{lcccc}
\hline Köpük Kodu & $\begin{array}{c}\mathbf{2 \theta}(\mathbf{0 0 2}) \\
\left({ }^{\circ}\right)\end{array}$ & $\begin{array}{c}\mathbf{d}_{\mathbf{0 0 2}} \\
(\mathbf{n m})\end{array}$ & $\begin{array}{c}\mathbf{2 \theta}(\mathbf{1 0 0}) \\
\left({ }^{\circ}\right)\end{array}$ & $\begin{array}{c}\mathbf{d}_{\mathbf{1 0 0}} \\
(\mathbf{n m})\end{array}$ \\
\hline$G Z C F$ & 23,43 & 0,3794 & 43,38 & 0,2084 \\
$G Z A C F$ & 21,33 & 0,4162 & 41,91 & 0,2154 \\
\hline
\end{tabular}




\begin{tabular}{|c|c|c|}
\hline & $\begin{array}{l}\text { BŞEÜ Fen Bilimleri Dergisi } \\
8(2), 1044-1056,2021\end{array}$ & $\begin{array}{r}\text { BSEU Journal of Science } \\
\text { https://doi.org/10.35193/bseufbd.1013724 }\end{array}$ \\
\hline & & :2458-7575 (https://dergipark.org.tr/tr/pub/bseufbd) \\
\hline
\end{tabular}

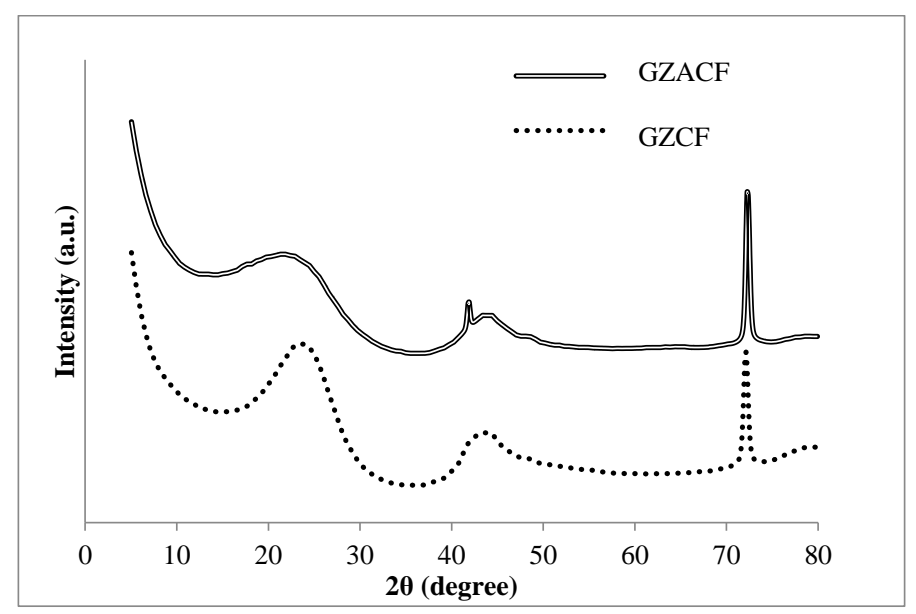

Şekil 6. $G Z C F$ ve $G Z A C F$ karbon köpüklerine ait x-ışını kırınım desenleri

Şekil 7'de sunulan GZCF ve GZACF köpüklerine ait SEM görüntüleri incelendiğinde, 100x büyütme oranında her iki karbon köpüğün de gözenekli yapıya sahip olduğu görülmüştür. GZCF karbon köpüğü $\mathrm{KOH}$ kullanılarak aktive edildiğinde üretilen GZACF köpüğünün hücre duvarlarında ve boğum noktalarında meydana gelen kırılmalara ek olarak yapıda mikro-çatlakların oluştuğu saptanmıştır. Yapıda oluşan bu değişim yüzey alanını arttırmakta ancak basma dayanımının düşmesine neden olmaktadır. Karbon köpüklerin yapısında 50-400 $\mu \mathrm{m}$ aralığında çeşitli boyutlarda hücrelerin bulunduğu belirlenmiştir.
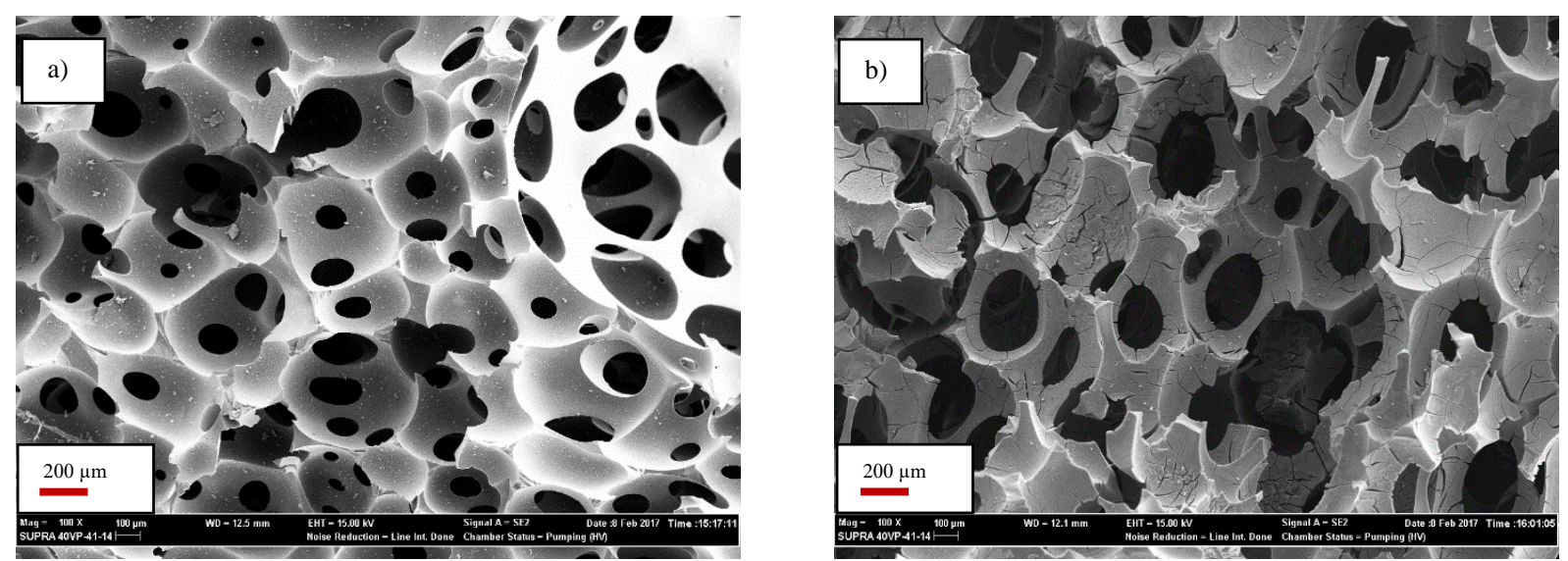

Şekil 7. SEM görüntüleri a) $G Z C F$ ve b) $G Z A C F$

Gözenekli malzemeler için önemli parametreler arasında yer alan yüzey alanı ve gözenek özellikleri azot sorpsiyon analizi uygulanarak belirlenmiştir. Karbon köpüklerin yüzey alanı, gözenek hacmi ve ortalama gözenek çapı değerleri Tablo 5'te, azot adsorpsiyon/desorpsiyon izotermleri ve gözenek boyut dağılım grafiği ise Şekil 8 'de verilmiştir. SEM analizinin desteklediği üzere, oldukça düşük bir değere sahip GZCF karbon köpügünün yüzey alanı $\left(59,821 \mathrm{~m}^{2} / \mathrm{g}\right)$, KOH ile kimyasal aktivasyon sonucu yapıda oluşan çatlaklara bağlı olarak $G Z A C F$ için $1004,184 \mathrm{~m}^{2} / \mathrm{g}$ değerine yükselmiştir. Bu durum, $G Z C F$ için $0,0366 \mathrm{~cm}^{3} / \mathrm{g}$ olan yapıdaki gözenek hacminin, $G Z A C F$ aktive karbon köpügüunde $0,4226 \mathrm{~cm}^{3} / \mathrm{g}$ değerine ulaşması ile uyum içindedir. IUPAC sınıflandırmasına göre mikro ve mezo gözeneklerin varlığını gösteren IV. tip izoterme ait eğilim karbon köpüklerin azot sorpsiyon izotermlerinde gözlenmiş ve her iki köpüğün de ortalama gözenek çapı değerlerinin 1,22 nm değerinde olduğu bulunmuştur. Gözenek boyut dağılımı grafiklerine göre, aktive edilen karbon köpüğün gözenek boyut dağılımının daha homojen olduğu belirlenmiştir. 


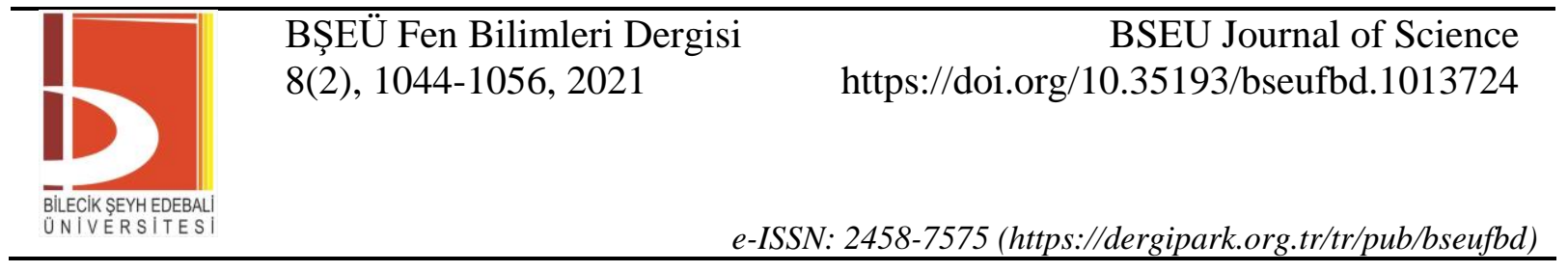

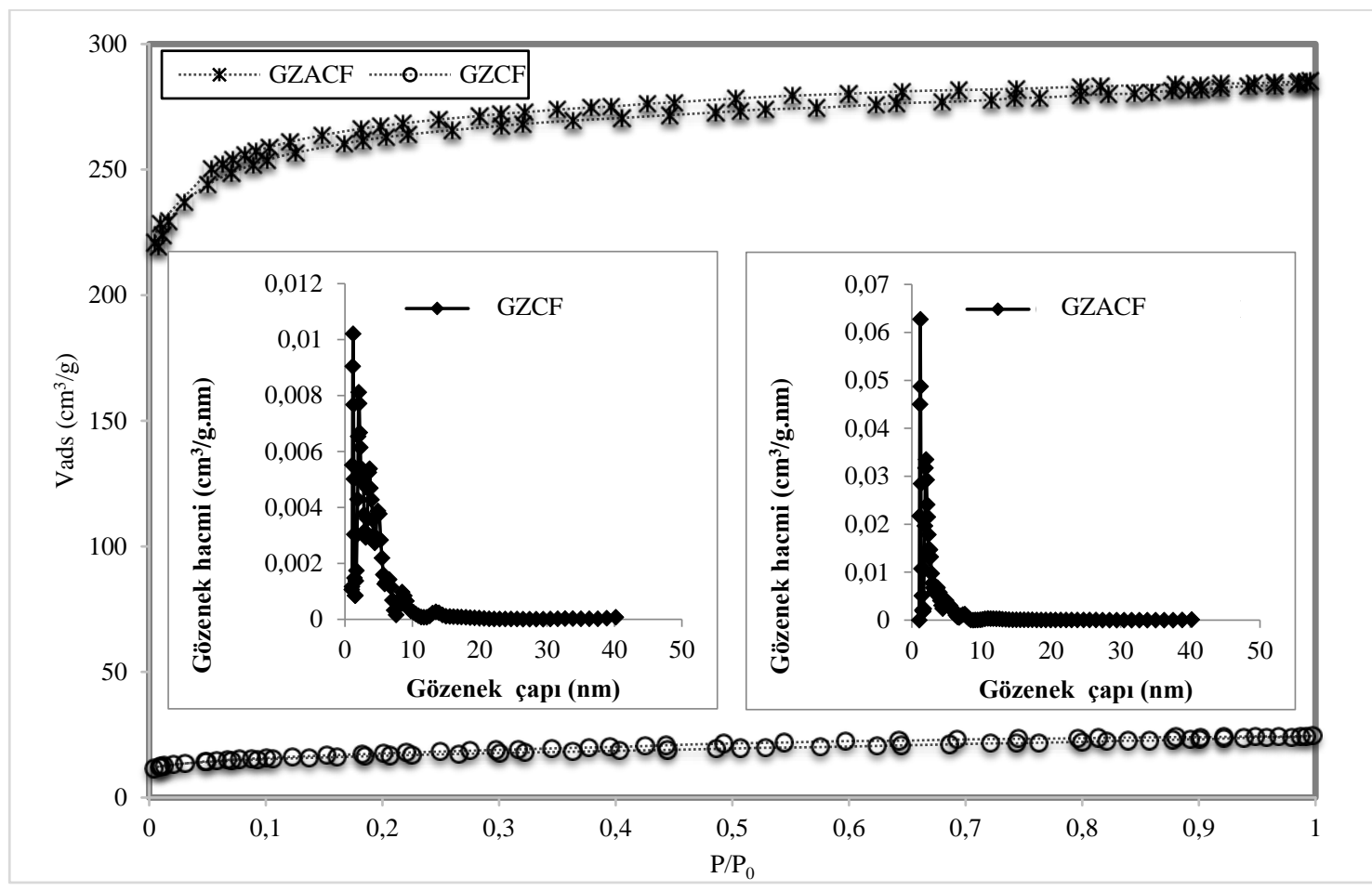

Şekil 8. Karbon köpükler için azot sorpsiyon izotermleri ve gözenek boyut dağılım grafikleri

Tablo 5. Karbon köpüklerin yapısal özellikleri

\begin{tabular}{lccccc}
\hline Köpük & $\begin{array}{c}\mathbf{S}_{\text {BET }} \\
\left(\mathbf{m}^{\mathbf{2}} \mathbf{g}\right)\end{array}$ & $\begin{array}{c}\mathbf{V}_{\text {toplam }} \\
\left(\mathbf{c m}^{3} / \mathbf{g}\right)\end{array}$ & $\begin{array}{c}\mathbf{V}_{\text {mikro }} \\
\left(\mathbf{c m}^{3} / \mathbf{g}\right)\end{array}$ & $\begin{array}{c}\mathbf{V}_{\text {mezo }} \\
\left(\mathbf{c m}^{3} / \mathbf{g}\right)\end{array}$ & $\begin{array}{c}\text { Ortalama gözenek } \\
\text { çapı (nm) }\end{array}$ \\
\hline$G Z C F$ & 59,821 & 0,0366 & 0,0177 & 0,0189 & 1,22 \\
$G Z A C F$ & 1004,184 & 0,4226 & 0,3919 & 0,0307 & 1,22 \\
\hline
\end{tabular}

Karbon köpüğün gözenek yapısı ve yoğunluğu ile ilişkili olan basma dayanımı değerlerine ait ölçüm sonuçları Tablo 6'da verilmiştir. Gözenekliliğin ve dolayısıyla yapıdaki gözenek hacminin artması ile basma dayanımı değerlerinde gözlenen düşüş literatürde gerçekleştirilen çalışmalar ile örtüşmektedir [35,63]. Yığın yoğunluk ve helyum piknometresi ile ölçülen gerçek yoğunluğa göre hesaplanan \% gözeneklilik değerlerine göre, kimyasal aktivasyon sonucu üretilen $G Z A C F$ karbon köpüğünün $G Z C F$ 'ye oranla $\% 4,2$ daha yüksek gözenekliliğe sahip olduğu belirlenmiş̧tir. Basma dayanımı testine göre 1,681 MPa dayanıma sahip GZCF karbon köpüğ̈̈ kimyasal aktivasyona uğradığında basma dayanımı değeri 0,258 MPa'a düşmüştür.

Tablo 6. Karbon köpüklerin yoğunluk, dayanım ve \% gözeneklilik değerleri

\begin{tabular}{lcccc}
\hline Köpük & $\begin{array}{c}\text { Dayanım } \\
\text { (MPa) }\end{array}$ & $\begin{array}{c}\text { Yığın } \\
\text { yoğunluk } \\
\left(\mathbf{g} / \mathbf{c m}^{\mathbf{3}}\right)\end{array}$ & $\begin{array}{c}\text { Gerçek } \\
\mathbf{y o g ̆ u n l u k} \\
\left(\mathbf{g} / \mathbf{c m}^{\mathbf{3}}\right)\end{array}$ & $\begin{array}{c}\text { Gözeneklilik } \\
(\boldsymbol{\%})\end{array}$ \\
\hline$G Z C F$ & 1,681 & 0,1879 & 1,6413 & 88,55 \\
$G Z A C F$ & 0,258 & 0,1545 & 1,9907 & 92,24 \\
\hline
\end{tabular}

\section{SONUÇLAR}

İleri teknoloji malzemeler arasında yaygın kullanım alanına sahip karbonlu malzemelerin üretiminde sürdürülebilir öncü maddelerin seçimi ve ürün özelliklerinin amaca uygun biçimde geliştirilmesine yönelik çalışmalar oldukça ilgi çekmektedir. Yapılan çalışmada, endüstriyel biyokütle atığı gürgen talaşının $400{ }^{\circ} \mathrm{C}$ 'de pirolizi ile üretilen katranın hafif bileşenlerinin uzaklaştırılması sonucu elde edilen biyoziftin karbon köpük hazırlanmasında öncü madde olarak kullanılması amaçlanmışıır. Ayrıca, $\mathrm{KOH}$ kullanılarak uygulanan kimyasal aktivasyon işleminin karbon köpüŭün elementel içeriği, morfolojik, kristalografik ve yapısal özellikleri üzerinde yaptığı değişiklikler ayrıntılı olarak incelenmiştir. Karbon köpük üretim sürecinde kullanılan gürgen talaşının C içeriği $(\% 45,99)$ göz önünde bulundurulduğunda, piroliz-zift üretimi-karbon köpük sentezi olmak üzere uygulanan 
her işlem sonrasında elde edilen ürünlerin hammaddeye kıyasla C içeriği açısından giderek artan bir eğilime sahip olduğu bulunmuştur. Buna karşılık, üretilen karbon köpüğe kimyasal aktivasyon işlemi uygulandığında \%5,04 oranında $\mathrm{C}$ içeriğinin azaldığı belirlenmiştir. X-1şını kırınımı analizine göre, karbon köpüklerin kırınım desenlerinin benzer olduğu ve karbonlu malzemelere ait karakteristik pikleri kapsadığı sonucuna ulaşılmıştır. Taramalı elektron mikroskobu görüntülerinden görüldüğü üzere, kimyasal aktivasyon sonucu yapıda oluşan değişimin yüzey alanını ve gözenek hacmini önemli derecede iyileştirdiği; buna bağlı olarak \%88,55 olan \% gözeneklilik değerinin \%92,24'e ulaştı̆̆ bulunmuştur. Buna karşılık, kimyasal aktivasyon işlemi ile malzemenin basma dayanımının \%84,65 oranında azaldığı, dolayısıyla daha kırılgan bir yapıya sahip olduğu belirlenmiştir. Gerçekleştirilen karakterizasyon işlemleri ile biyo-esaslı karbon köpüklerin üretim sürecinde uygulanan çalışma koşullarının düzenlenmesi ile kullanım amacına uygun özelliklerde malzemelerin hazırlanabileceği sonucuna ulaşılmıştır. Üretilen karbon köpüklerin katalizör destek malzemesi, adsorban ya da 1sıl yalıtım malzemesi olarak kullanılabilirliği göz önünde bulundurulduğunda karakteristik özelliklerinin ayarlanabilir olması önemli bir avantaj sağlamaktadır. Ürün özellikleri dikkate alınarak, ilerleyen çalışmalarda köpükleşme sürecinde farklı şablon malzemelerinin kullanılması ile karbon köpük yapısında meydana gelecek özelliklerin araştırılması planlanmaktadır.

\section{TEŞEKKÜR}

Bu çalışma, TÜBİTAK 219M104 no’lu projenin bir parçası olarak desteklenmiş olup, yazarlar TÜBİTAK'a teşekkürü bir borç bilirler.

\section{KAYNAKLAR}

[1] Suda, H., \& Haraya, K. (1997). Alkene/alkane permselectivities of a carbon molecular sieve membrane. Chemical Communications, (1), 93-94.

[2] Velasco, L. F., Tsyntsarski, B., Petrova, B., Budinova, T., Petrov, N., Parra, J. B., \& Ania, C. O. (2010). Carbon foams as catalyst supports for phenol photodegradation. Journal of Hazardous Materials, 184(1-3), 843-848.

[3] Rodriguez-Reinoso, F. (1998). The role of carbon materials in heterogeneous catalysis. Carbon, 36(3), 159175.

[4] Lv, Y., Liu, M., Gan, L., Cao, Y., Chen, L., Xiong, W., Xu, Z., Hao, Z., Liu, H, \& Chen, L. (2011). Synthesis of sodium-vanadate-doped ordered mesoporous carbon foams as capacitor electrode materials. Chemistry Letters, 40(3), 236-238.

[5] Wang, D. W., Li, F., Liu, M., Lu, G. Q., \& Cheng, H. M. (2008). 3D aperiodic hierarchical porous graphitic carbon material for high-rate electrochemical capacitive energy storage. Angewandte Chemie International Edition, 47(2), 373-376.

[6] Rolison, D. R. (2003). Catalytic nanoarchitectures--the importance of nothing and the unimportance of periodicity. Science, 299(5613), 1698-1701.

[7] Morishita, T., Soneda, Y., Tsumura, T., \& Inagaki, M. (2006). Preparation of porous carbons from thermoplastic precursors and their performance for electric double layer capacitors. Carbon, 44(12), 23602367.

[8] Chmiola, J., Yushin, G., Gogotsi, Y., Portet, C., Simon, P., \& Taberna, P. L. (2006). Anomalous increase in carbon capacitance at pore sizes less than 1 nanometer. Science, 313(5794), 1760-1763.

[9] Thess, A., Lee, R., Nikolaev, P., Dai, H., Petit, P., Robert, J., Xu, C. H., Lee, Y. H., Kim, S. G., Rinzler, A. G., Colbert, D. T., Scuseria, G. E., Tomanek, D., Fischer, J. E., \& Smalley, R. E. (1996). Crystalline ropes of metallic carbon nanotubes. Science, 273(5274), 483-487.

[10] Journet, C., Maser, W. K., Bernier, P., Loiseau, A., de La Chapelle, M. L., Lefrant, D. S., Deniard, P., Lee, R., \& Fischer, J. E. (1997). Large-scale production of single-walled carbon nanotubes by the electric-arc technique. Nature, 388(6644), 756-758.

[11] Zheng, B., Lu, C., Gu, G., Makarovski, A., Finkelstein, G., \& Liu, J. (2002). Efficient CVD growth of singlewalled carbon nanotubes on surfaces using carbon monoxide precursor. Nano Letters, 2(8), 895-898.

[12] Liu, M., Gan, L., Tian, C., Zhu, J., Xu, Z., Hao, Z., \& Chen, L. (2007). Mesoporous carbon foams through surfactant templating. Carbon, 15(45), 3045-3046.

[13] Kim, T. W., Park, I. S., \& Ryoo, R. (2003). A synthetic route to ordered mesoporous carbon materials with graphitic pore walls. AngewandteChemie, 42(36), 4375-4379.

[14] Xu, B., Wu, F., Chen, R., Cao, G., Chen, S., \& Yang, Y. (2010). Mesoporous activated carbon fiber as electrode material for high-performance electrochemical double layer capacitors with ionic liquid electrolyte. Journal of Power Sources, 195(7), 2118-2124. 
[15] Jang, Y. I., Dudney, N. J., Tiegs, T. N., \& Klett, J. W. (2006). Evaluation of the electrochemical stability of graphite foams as current collectors for lead acid batteries. Journal of Power Sources, 161(2), 1392-1399.

[16] Liu, H. J., Wang, X. M., Cui, W. J., Dou, Y. Q., Zhao, D. Y., \& Xia, Y. Y. (2010). Highly ordered mesoporous carbon nanofiber arrays from a crab shell biological template and its application in supercapacitors and fuel cells. Journal of Materials Chemistry, 20(20), 4223-4230.

[17] Raymundo-Piñero, E., Leroux, F., \& Béguin, F. (2006). A high-performance carbon for supercapacitors obtained by carbonization of a seaweed biopolymer. Advanced Materials, 18(14), 1877-1882.

[18] Ruan, G., Sun, Z., Peng, Z., \& Tour, J. M. (2011). Growth of graphene from food, insects, and waste. ACS Nano, 5(9), 7601-7607.

[19] Lv, Y., Gan, L., Liu, M., Xiong, W., Xu, Z., Zhu, D., \& Wright, D. S. (2012). A self-template synthesis of hierarchical porous carbon foams based on banana peel for supercapacitor electrodes. Journal of Power Sources, 209, 152-157.

[20] Sun, L., Wan, S., Yuan, D., \& Yu, Z. (2019). Adsorption of nitroimidazole antibiotics from aqueous solutions on self-shaping porous biomass carbon foam pellets derived from Vallisnerianatans waste as a new adsorbent. Science of the Total Environment, 664, 24-36.

[21] Song, S. A., Lee, Y., Kim, Y. S., \& Kim, S. S. (2017). Mechanical and thermal properties of carbon foam derived from phenolic foam reinforced with composite particles. Composite Structures, 173, 1-8.

[22] Liu, M., Gan, L., Zhao, F., Fan, X., Xu, H., Wu, F., Xu, Z., Hao, Z., \& Chen, L. (2007). Carbon foams with high compressive strength derived from polyarylacetylene resin. Carbon, 15(45), 3055-3057.

[23] Zhou, P., \& Chen, Q. L. (2016). Preparation and characterization of carbon foam derived from coal pitch. Journal of Analytical and Applied Pyrolysis, 122, 370-376.

[24] Fawcett, W., \& Shetty, D. K. (2010). Effects of carbon nanofibers on cell morphology, thermal conductivity and crush strength of carbon foam. Carbon, 48(1), 68-80.

[25] Mochida, I., Korai, Y., Ku, C. H., Watanabe, F., \& Sakai, Y. (2000). Chemistry of synthesis, structure, preparation and application of aromatic-derived mesophase pitch. Carbon, 38(2), 305-328.

[26] Li, J., Wang, C., Zhan, L., Qiao, W. M., Liang, X. Y., \& Ling, L. C. (2009). Carbon foams prepared by supercritical foaming method. Carbon, 47(4), 1204-1206.

[27] Lei, S., Guo, Q., Shi, J., \& Liu, L. (2010). Preparation of phenolic-based carbon foam with controllable pore structure and high compressive strength. Carbon, 48(9), 2644-2646.

[28] Min, G., Zengmin, S., Weidong, C., \& Hui, L. (2007). Anisotropy of mesophase pitch-derived carbon foams. Carbon, 45(1), 141-145.

[29] Zhang, C., Wang, C., Zhan, L., Wang, C., Wang, Y., \& Ling, L. (2011). Synthesis of carbon foam covered with carbon nanofibers as catalyst support for gas phase catalytic reactions. Materials Letters, 65(12), 18891891.

[30] Li, T. Q., Wang, C. Y., An, B. X., \& Wang, H. (2005). Preparation of graphitic carbon foam using sizerestriction method under atmospheric pressure. Carbon, 43(9), 2030-2032.

[31] Petrova, B., Tsyntsarski, B., Budinova, T., Petrov, N., Velasco, L. F., \& Ania, C. O. (2011). Activated carbon from coal tar pitch and furfural for the removal of p-nitrophenol and m-aminophenol. Chemical Engineering Journal, 172(1), 102-108.

[32] Wang, L., Wang, J., Jia, F., Wang, C., \& Chen, M. (2013). Nanoporous carbon synthesised with coal tar pitch and its capacitive performance. Journal of Materials Chemistry A, 1(33), 9498-9507.

[33] He, X., Zhao, N., Qiu, J., Xiao, N., Yu, M., Yu, C., Zhang, X., \& Zheng, M. (2013). Synthesis of hierarchical porous carbons for supercapacitors from coal tar pitch with nano-Fe $2 \mathrm{O} 3$ as template and activation agent coupled with $\mathrm{KOH}$ activation. Journal of Materials Chemistry A, 1(33), 9440-9448.

[34] Li, D., Li, Y., Liu, H., Ma, J., Liu, Z., Gai, C., \& Jiao, W. (2019). Synthesis of biomass tar-derived foams through spontaneous foaming for ultra-efficient herbicide removal from aqueous solution. Science of the Total Environment, 673, 110-119.

[35] Yargic, A. S., \& Ozbay, N. (2019). Effect of chemical activation on the cellular structure of biopitch-derived green carbon foam. Diamond and Related Materials, 96, 58-66.

[36] Yargic, A. S. (2021). Current Engineering Sciences Research, Chapter-1-Conversion of Biopitch to Carbon Foam with Tunable Properties: The Role of Chemical Activation, Livre de Lyon, Lyon,1-22.

[37] Ozbay, N., \& Yargic, A. S. (2019). Carbon foam production from bio-based polyols of liquefied spruce tree sawdust: Effects of biomass/solvent mass ratio and pyrolytic oil addition. Journal of Applied Polymer Science, 136(11), 47185.

[38] Tondi, G., Pizzi, A., Delmotte, L., Parmentier, J., \& Gadiou, R. (2010). Chemical activation of tannin-furanic carbon foams. Industrial Crops and Products, 31(2), 327-334. 
[39] Harker, J. H., \& Backhurst, J. R. (1981). Fuel and energy. Academic Press Limited, London.

[40] Yargıç, A. Ş., Şahin, R. Z. Y., \& Özbay, N (2021). Biyo-poliol-esaslı karbon köpüğün yapısal özellikleri üzerinde çözücü türü etkisinin incelenmesi. Gazi Üniversitesi Mühendislik Mimarlık Fakültesi Dergisi, 36(1), 133-146.

[41] Apaydın-Varol, E., \& Erülken, Y. (2015). A study on the porosity development for biomass based carbonaceous materials. Journal of the Taiwan Institute of Chemical Engineers, 54, 37-44.

[42] Xu, G.,Yang, T., Fang, Z., Wang, Q., Yang, C., \& Zhao, X. (2018). Preparation and characterization of coalbased carbon foams by microwave heating process under ambient pressure. Diamond and Related Materials, 86, 63-70.

[43] Sun, Y., \& Webley, P. A. (2011). Preparation of activated carbons with large specific surface areas from biomass corncob and their adsorption equilibrium for methane, carbon dioxide, nitrogen, and hydrogen. Industrial \& Engineering Chemistry Research, 50(15), 9286-9294.

[44] Prauchner, M. J., Pasa, V. M., \& de Menezes, S. M. (2001). Solid-state 13C NMR quantitative study of Eucalyptus tar pitches. Journal of Wood Chemistry and Technology, 21(4), 371-385.

[45] Prauchner, M. J., Pasa, V. M., Otani, C., Otani, S., \& de Menezes, S. M. (2004). Eucalyptus tar pitch pretreatment for carbon material processing. Journal of Applied Polymer Science, 91(3), 1604-1611.

[46] Prauchner, M. J., Pasa, V. M., Otani, C., \& Otani, S. (2001). Characterization and thermal polymerization of Eucalyptus tar pitches. Energy \& Fuels, 15(2), 449-454.

[47] Araujo, R. C. S., \& Pasa, V. M. D. (2003). Mechanical and thermal properties of polyurethane elastomers based on hydroxyl-terminated polybutadienes and biopitch. Journal of Applied Polymer Science, 88(3), 759766.

[48] Araújo, R. C. S., \& Pasa, V. M. D. (2004). New Eucalyptus tar-derived polyurethane coatings. Progress in Organic Coatings, 51(1), 6-14.

[49] Melo, B. N., \& Pasa, V. M. (2003). Composites based on eucalyptus tar pitch/castor oil polyurethane and short sisal fibers. Journal of Applied Polymer Science, 89(14), 3797-3802.

[50] Gamlen, P. H., \& White, J. W. (1976). Structure and dynamics of microcrystalline graphite, graphon, by neutron scattering. Journal of the Chemical Society, Faraday Transactions 2: Molecular and Chemical Physics, 72, 446-455.

[51] Girgis, B. S., Yunis, S. S., \& Soliman, A. M. (2002). Characteristics of activated carbon from peanut hulls in relation to conditions of preparation. Materials Letters, 57(1), 164-172.

[52] Lopez, F. A., Centeno, T. A., Garcia-Diaz, I., \& Alguacil, F. J. (2013). Textural and fuel characteristics of the chars produced by the pyrolysis of waste wood, and the properties of activated carbons prepared from them. Journal of Analytical and Applied Pyrolysis, 104, 551-558.

[53] Tushar, M. S. H. K., Mahinpey, N., Khan, A., Ibrahim, H., Kumar, P., \& Idem, R. (2012). Production, characterization and reactivity studies of chars produced by the isothermal pyrolysis of flax straw. Biomass and Bioenergy, 37, 97-105.

[54] Zhang, S., Zheng, M., Lin, Z., Li, N., Liu, Y., Zhao, B., Pang, H., Cao, J., He, P. \& Shi, Y. (2014). Activated carbon with ultrahigh specific surface area synthesized from natural plant material for lithium-sulfur batteries. Journal of Materials Chemistry A, 2(38), 15889-15896.

[55] Prauchner, M. J., Pasa, V. M., Molhallem, N. D., Otani, C., Otani, S., \& Pardini, L. C. (2005). Structural evolution of Eucalyptus tar pitch-based carbons during carbonization. Biomass and Bioenergy, 28(1), 53-61.

[56] Wang, M. X., Wang, C. Y., Li, T. Q., \& Hu, Z. J. (2008). Preparation of mesophase-pitch-based carbon foams at low pressures. Carbon, 46(1), 84-91.

[57] Hull, A. (1926). Berichte der Deutschen Chemischen Gesellschaft, 59, 2433-2444.

[58] Li, W., Huang, Z., Wu, Y., Zhao, X., \& Liu, S. (2015). Honeycomb carbon foams with tunable pore structures prepared from liquefied larch sawdust by self-foaming. Industrial Crops and Products, 64, 215-223.

[59] Lipson, H., \&Stokes, A. R. (1942). A new structure of carbon. Nature, 149(3777), 328-328.

[60] Wang, R., Li, W., \& Liu, S. (2012). A porous carbon foam prepared from liquefied birch sawdust. Journal of Materials Science, 47(4), 1977-1984.

[61] Strano, M. S., Zydney, A. L., Barth, H., Wooler, G., Agarwal, H., \& Foley, H. C. (2002). Ultrafiltration membrane synthesis by nanoscale templating of porous carbon. Journal of Membrane Science, 198(2), 173186.

[62] Fayos, J. (1999). Possible 3D carbon structures as progressive intermediates in graphite to diamond phase transition. Journal of Solid State Chemistry, 148(2), 278-285.

[63] Luo, X., Mohanty, A., \& Misra, M. (2013). Lignin as a reactive reinforcing filler for water-blown rigid biofoam composites from soy oil-based polyurethane. Industrial Crops and Products, 47, 13-19. 